\title{
Soil Suppressiveness to Fusarium Disease: Shifts in Root Microbiome Associated with Reduction of Pathogen Root Colonization
}

\author{
Eyal Klein, Maya Ofek, Jaacov Katan, Dror Minz, and Abraham Gamliel
}

First, second, and third authors: Department of Plant Pathology and Microbiology, The Hebrew University of Jerusalem, The Robert H. Smith Faculty of Agriculture, Food, and Environment, Rehovot 76100, Israel; first and fifth authors: Laboratory for Pest Management Research, Institute of Agricultural Engineering, and second and fourth authors: Institute of Soil, Water, and Environmental Sciences ARO, The Volcani Center, Bet Dagan 50250, Israel.

Accepted for publication 28 August 2012.

\begin{abstract}
Klein, E., Ofek, M., Katan, J., Minz, D., and Gamliel, A. 2013. Soil suppressiveness to Fusarium disease: Shifts in root microbiome associated with reduction of pathogen root colonization. Phytopathology 103:23-33.

Soil suppressiveness to Fusarium disease was induced by incubating sandy soil with debris of wild rocket (WR; Diplotaxis tenuifolia) under field conditions. We studied microbial dynamics in the roots of cucumber seedlings following transplantation into WR-amended or nonamended soil, as influenced by inoculation with Fusarium oxysporum f. sp. radicisсиситеrinum. Disease symptoms initiated in nonamended soil 6 days after inoculation, compared with 14 days in WR-amended soil. Root infection by $F$. oxysporum f. sp. radicis-cucumerinum was quantified using real-time polymerase chain reaction (PCR). Target numbers were similar 3 days after inoculation for both WR-amended and nonamended soils, and were significantly lower (66\%) 6 days after inoculation and transplanting into the suppressive (WR-amended) soil. This decrease in root colonization was correlated with a reduction in disease (60\%) 21 days after inoculation and transplanting into the suppressive soil. Fungal community composition on cucumber roots was assessed using mass sequenc-

an unclassified Ascomycota composed $96 \%$ of the total fungal sequences in all samples. The relative abundances of these major groups were highly affected by root inoculation with $F$. oxysporum f. sp. radicis-cucumerinum, with a 10 -fold increase in $F$. oxysporum sequences, but were not affected by the WR amendment. Quantitative analysis and mass-sequencing methods indicated a qualitative shift in the root's bacterial community composition in suppressive soil, rather than a change in bacterial numbers. A sharp reduction in the size and root dominance of the Massilia population in suppressive soil was accompanied by a significant increase in the relative abundance of specific populations; namely, Rhizobium, Bacillus, Paenibacillus, and Streptomyces spp. Composition of the Streptomyces community shifted significantly, as determined by PCR denaturing gradient gel electrophoresis, resulting in an increase in the dominance of a specific population in suppressive soils after only 3 days. This shift was related mainly to the increase in Streptomyces humidus, a group previously described as antagonistic to phytopathogenic fungi. Thus, suitable soil amendment resulted in a shift in the root's bacterial communities, and infection by a virulent pathogen was contained by the root microbiome, leading to a reduced disease rate.
\end{abstract} ing of fungal internal transcribed spacer gene fragments. Sequences related to F. oxysporum, Fusarium sp. 14005, Chaetomium sp. 15003, and
Additional keyword: fingerprint.
Incorporation of certain organic amendments into soil may induce soil suppressiveness against soilborne as well as foliar pathogens. The process involves biological control mechanisms, which have the potential to persist in the treated soils for an extended period of time $(33,41,47,64,66)$. Disease incidence or severity remains low in suppressive soils, even after repeated introduction of a pathogen (15).

The soil microbiome plays a significant role in natural and induced disease suppression. The possible mechanisms of induced soil suppressiveness include pathogen suppression $(13,65)$, induced systemic resistance within the host $(34,55,76)$, and microbial interactions which take place in the rhizosphere. The latter involve mechanisms such as competition for nutrients and antibiosis $(44,58)$. The mechanisms of soil suppressiveness have been extensively studied by classical means, such as in culture and by direct root-microbe analysis $(20,62)$.

Molecular methods are effective tools to characterize soil and rhizosphere microbiomes $(8,9,43,46,49)$ for the purpose of identifying predictive microbial parameters for disease suppressiveness and potential antagonists that can be used as biological control agents $(7,9,56,75)$. However, adoption of metagenomic ap-

Corresponding author: A. Gamliel; E-mail address: agamliel@agri.gov.il

http://dx.doi.org/10.1094/PHYTO-12-11-0349

(c) 2013 The American Phytopathological Society proaches for soil microbial ecology have revealed the enormous complexity of the microbial interactions in such environments $(5,67)$. Such a detailed and accurate characterization of the microbial interactions can indicate possible suppressive mechanisms and assist in identifying factors that enhance them.

Plant host, soil type, and physical and chemical environments are important factors in establishing the platform upon which microbial interactions that will exhibit soil suppressiveness occur (32). Available information clearly indicates that the microbial mechanisms of soil suppressiveness involve the activity of consortia of diverse microbial populations, rather than one specific organism population $(44,49)$. Much effort has been invested in characterizing microorganisms and their genetic elements, which are related to disease suppression in the bulk and rhizosphere of suppressive soils $(9,35,49,56,69)$. In contrast, less attention has been paid to microbial events at the site of the host-pathogen interaction - the root itself-during different stages of pathogen infection and disease development in disease-suppressive or -conducive soils $(62,74)$. Early findings indicate that organisms are attracted to plant roots at early stages of seed germination and root development $(4,12,52)$. Hence, a temporal analysis of the microbial interactions at different stages of pathogen infection is essential for understanding the mechanisms underlying soil-suppressive interactions. Data on soil microbial population do not necessarily reflect in the microbial situation in the root tissues (19). Highly sensitive methods for microbial ecology charac- 
terization, such as mass sequencing of 16S rRNA gene fragments, can increase the observational resolution of these microbial interactions in a pathosystem. In a previous work (33), we demonstrated that organic amendments, such as herb residues, induce suppressiveness in soil against Fusarium crown and root rot in cucumber. The objectives of the current study were to characterize the microbial events taking place in the root environment, during pathogen establishment, under conducive and suppressive soil conditions. For this purpose, we studied Fusarium crown and root rot establishment in cucumber roots after inoculation and at symptom appearance. The effect of induced soil suppression on the microbial colonization of roots was characterized by mass sequencing of $16 \mathrm{~S}$ rRNA and internal transcribed spacer (ITS) gene fragments, qualitative analyses with polymerase chain reaction denaturing gradient gel electrophoresis (PCR-DGGE), and quantitative examination of the root microbiome.

\section{MATERIALS AND METHODS}

Inducing soil suppressiveness with wild rocket residues. Soil suppressiveness to Fusarium wilt and crown rot of cucumber was induced as described previously (33). Briefly, ground dried leaves and stems of Diplotaxis tenuifolia (L.) DC. (wild rocket [WR]) were mixed with sandy soil from Rehovot (94\% sand, $2 \%$ silt, $4 \%$ clay, and $0.12 \%$ organic matter, $\mathrm{pH} 7.9$; field capacity of $9 \%$ ) at a rate of $1 \%(\mathrm{wt} / \mathrm{wt})$. The soil-WR mixture was wetted to waterholding capacity and was packed in a porous, woven plastic net bag (total $22 \mathrm{~kg} / \mathrm{bag}$ ). Nonamended soil was prepared and packed similarly, and served as the respective control. The bags containing the amended and nonamended wetted soils were buried in separate small field plots, mulched with a transparent polyethylene sheet, and additionally covered with a shading screen (90\% shade; Polysak, Nir Itzhak, Israel) which was laid over the plastic mulch to minimize soil heating (soil temperature at a $20-\mathrm{cm}$ depth reached a maximum 32 to $34^{\circ} \mathrm{C}$ in the shaded plots). After 28 days in the field, the soil bags were retrieved with their contents and brought to the laboratory. The soil was left to air dry at $25^{\circ} \mathrm{C}$ for 1 month prior to its use for assessing suppressiveness.

Soil suppressiveness to Fusarium crown and root rot in cucumber. Fusarium oxysporum f. sp. radicis-cucumerinum Vakal., the causal agent of cucumber root and crown rot disease, was used for the pathosystem and suppressiveness tests. Cucumber (Cucumis sativus L. 'Kfir') seedlings were inoculated with $F$. oxysporum f. sp. radicis-cucumerinum macroconidia obtained from the stem surface of diseased plants and transplanted in WR- amended (suppressive) and nonamended (control) soil in pot experiments, as previously described (32). Disease symptoms in cucumber seedlings usually appear 7 days after inoculation and are manifested as plant collapse and wilt. Disease progress was expressed as percentage of diseased plants, determined by area under the disease progress curve (AUDPC). Soil suppressiveness was calculated as the reduction in disease incidence or severity in amended soil compared with the respective nonamended soil.

Root sampling. Root-microbiome analyses were conducted in cucumber transplants inoculated with $F$. oxysporum f. sp. radiciscucumerinum, planted in suppressive or control soils, and grown for 3 days (before symptom appearance) or 6 days (first appearance of light chlorosis of the leaves on inoculated control plants). On each date, cucumber transplants were removed with their entire root system from the pots (three plants per replicate, five replicates per treatment). The roots were cut and washed in $30 \mathrm{ml}$ of sterile saline water, using orbital vortexing for $1 \mathrm{~min}$ in three intervals. The washed roots were weighed, transferred to $15-\mathrm{ml}$ sterile tubes, and kept at $-20^{\circ} \mathrm{C}$ until DNA extraction.

DNA extraction. Extraction of DNA was carried out using the PowerSoil DNA Isolation Kit (Mo Bio Laboratories, Inc., Carlsbad, CA) as described by the manufacturer. DNA concentrations and quality were determined with an ND1000 spectrophotometer (NanoDrop Technologies, Wilmington, DE).

Real-time quantitative PCR. Real-time PCR was used for the quantification of total bacteria, plant plastid, Massilia spp., Streptomyces spp., F. oxysporum f. sp. radicis-cucumerinum, and the plant tef gene in root samples. The plant tef gene, encoding translation elongation factor 1 , served for data normalization as proposed by Ruppel et al. (59). A primer pair targeting the plant plastid was applied to correct bacterial target numbers for plant plastids according to Ofek et al. (53). The primers used for the different assays are listed in Table 1.

To verify primer specificity, a plasmid standard containing the target region was generated for each primer set. For this purpose, PCR products for each primer pair were amplified from root DNA samples as template. The PCR-amplified products were examined by gel electrophoresis to confirm the specificity of the amplification. In addition, each of the products was cloned using the TOPO TA Cloning Kit (Invitrogen, Carlsbad, CA) as instructed by the manufacturer. Plasmids were isolated and 10 randomly selected cloned inserts were sequenced from each primer set to confirm their identity and primer specificity. The specificity of $F$. oxysporum f. sp. radicis-cucumerinum primers, used following Lievens et al. (39), was also confirmed by PCR of DNA extracted from different pathogenic Fusarium strains, including F. oxy-

TABLE 1. Primers used in this study

\begin{tabular}{|c|c|c|c|c|}
\hline Primer & Sequence & Gene & Target organisms & Reference \\
\hline ITS1f & 5'-CTTGGTCATTTAGAGGAAGTAA-3' & fungal rRNA ITS & Fungi & 10 \\
\hline ITS2 & 5'-GCTGCGTTCTTCATCGATGC-3' & fungal rRNA ITS & Fungi & 10 \\
\hline $530 \mathrm{f}$ & 5'-GTGCCAGCMGCNGCGG-3' & $16 \mathrm{~S}$ rRNA & Bacteria & 17 \\
\hline $1100 \mathrm{r}$ & 5'- GGGTTNCGNTCGTTG-3' & $16 \mathrm{~S}$ rRNA & Bacteria & 17 \\
\hline $341 \mathrm{f}^{\mathrm{Z}}$ & 5'-GCCTACGGGAGGCAGCAG-3' & $16 \mathrm{~S}$ rRNA & Bacteria & 50 \\
\hline $907 \mathrm{r}$ & 5'-CCGTCAATTCMTTTGAGTTT-3' & $16 \mathrm{~S}$ rRNA & Bacteria & 50 \\
\hline $515 f$ & 5'-GTGCCAGCMGCCGCGGTAA-3' & $16 \mathrm{~S}$ rRNA & Universal & 36 \\
\hline Plast_f & 5'-GAGGCAATAGCTTACCAAGGCG-3' & $16 \mathrm{~S}$ rRNA & Plant plastid & 53 \\
\hline Plast_r & 5'-CTTGGTAGTTTCCACCGCCTG-3' & $16 \mathrm{~S}$ rRNA & Plant plastid & 53 \\
\hline Strep661f & 5'-GTAGGGGAGATCGGAATT-3' & $16 \mathrm{~S}$ rRNA & Streptomyces & 29 \\
\hline Sterp $1218 \mathrm{r}^{\mathrm{z}}$ & 5'-AGCACGTGTGCAGCCCAA-3' & $16 \mathrm{~S}$ rRNA & Streptomyces & 29 \\
\hline Oxalo225f & 5'-GGGTTGGCGGCCCTCTG-3' & $16 \mathrm{~S}$ rRNA & Oxalobacteraceae & 23 \\
\hline Mass656r & 5'-TTCTAGCCTTGCAGTCTCCATC-3' & $16 \mathrm{~S}$ rRNA & Massilia & 16 \\
\hline Tef_f & 5'-ACTGTGCAGTAGTACTTGGTG-3' & Translation elongation factor 1 & Plants & 70 \\
\hline Tef_r & 5'-AAGCTAGGAGGTATTGACAAG-3' & Translation elongation factor 1 & Plants & 70 \\
\hline FORC F5 & 5'-TCGTCACAATGATTTCAGCAT-3' & RAPD SCAR marker & Fusarium oxysporum f. sp. radicis-cucumerinum & 39 \\
\hline FORCR2 & 5'-GTGACGCAGGGTAGGCAT-3' & RAPD SCAR marker & F. oxysporum f. sp. radicis-cucumerinum & 39 \\
\hline
\end{tabular}

y ITS = internal transcribed spacer, RAPD SCAR = random amplified polymorphic DNA sequence characterized amplified region.

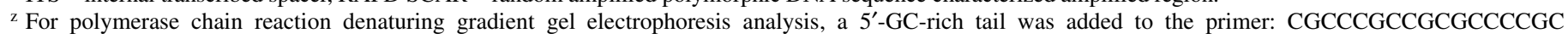
GCCCGTCCCGCCGCCCCCGCCC (49). 
sporum f. sp. melonis, F. oxysporum f. sp. radicis-lycopersici, and F. oxysporum f. sp. proliferatum. Plasmid DNA concentrations were determined spectrophotometrically, copy numbers were calculated accordingly, and 10-fold dilution series within a range of $10^{9}$ to 10 copies/ $\mu$ l were then prepared.

Real-time PCR assays were conducted in an Mx3000P QPCR System (Stratagene, La Jolla, CA) in 96-well polypropylene plates. Each well contained a $25-\mu \mathrm{l}$ mixture consisting of $12.5 \mu \mathrm{l}$ of Absolute Blue SYBR Green ROX Mix (Thermo Fisher Scientific, Surrey, UK), $1 \mu \mathrm{l}$ of each primer $(10 \mu \mathrm{M}$ final concentration), $9.5 \mu \mathrm{l}$ of $\mathrm{H}_{2} \mathrm{O}$, and $1 \mu \mathrm{l}$ of template DNA. The PCR conditions were $15 \mathrm{~min}$ at $95^{\circ} \mathrm{C}$, followed by 40 cycles of $95^{\circ} \mathrm{C}$ for $30 \mathrm{~s}, 60^{\circ} \mathrm{C}$ (or $58^{\circ} \mathrm{C}$ for the bacterial primer pair) for $30 \mathrm{~s}$, and $72^{\circ} \mathrm{C}$ for $30 \mathrm{~s}$. Melting-curve analysis of the PCR products was conducted following each assay to confirm specificity. The PCR products were also examined by agarose gel electrophoresis to confirm the specificity of amplification. Results were analyzed using MxPro QPCR Software analysis tools (Stratagene).

PCR-DGGE. Streptomyces spp.-specific population patterns were examined using the PCR-DGGE method. DNA extracted from different root samples served as the template for PCR amplification of Streptomyces 16S rRNA gene fragments using primers Strep661f and Strep1218r(GC) (Table 1), performed as previously described (29). DGGE was performed in $6 \%(\mathrm{wt} / \mathrm{vol})$ acrylamide gels containing a linear urea-formamide gradient of 20 to $70 \%$ denaturant (with $100 \%$ defined as $7 \mathrm{M}$ urea and $40 \%$ [vol/vol] formamide). Gels were run for $17 \mathrm{~h}$ at $100 \mathrm{~V}$ with the Dcode Universal Mutation System (Bio-Rad Laboratories, Hercules, CA). DNA was visualized after staining with Gelstar (Invitrogen) by UV transillumination $(302 \mathrm{~nm})$ and was photographed with a Kodak KDS digital camera. DGGE images were analyzed using Fingerprinting II software (Bio-Rad Laboratories), and an unweighted pair-group method with arithmetic means tree based on cosine correlation matrix was produced. Aligned densitometric curves were exported from the Fingerprint II software and multidimensional scaling analysis was performed based on 1-Pearson $r$ distance matrix using STATISTICA software (version 7.1; Stat Soft Inc., Tulsa, OK). Specific bands were excised from the gels. Band DNA was reamplified by PCR and verified on another DGGE, analyzed, and cloned using the TOPO TA Cloning Kit. Plasmids were isolated and sequenced. Phylogenetic affiliation of the retrieved sequences was determined using ARB software (42) and National Center for Biotechnology Information (NCBI) Blast analyses (3).

Sequencing of 16S rRNA gene fragments. DNA extracted from the root samples was subjected to mass sequencing. Bacterial 16S rDNA and fungal ITS tag-encoded FLX amplicon pyrosequencing were performed by the Research and Testing Laboratory (Lubbock, TX), as described by Dowd et al. (17). Primers are listed in Table 1 . The retrieved sequences were analyzed using MOTHUR (60). Five replicates were analyzed for each treatment at 3 and 6 days. For the root samples taken from inoculated WR-amended soil 3 days after transplantation, only four of the five replicates produced results in the fungal ITS assay (preparation of one sample library failed).

For fungal ITS, low-quality sequences and those shorter than 320 bases were omitted from further analyses. Then, suspected chimeras were detected using the MOTHUR chimera.check module $(\approx 10 \%$ of the total sequences) and eliminated from further analysis. The sequences were aligned using ARB software (42) and the alignment was exported to MOTHUR, where a distance matrix was calculated using the MOTHUR dis.seqs module. Sequences were then classified into operational taxonomic units (OTUs) using a 99\% sequence-similarity threshold. Representatives of each OTU were classified by NCBI Blast analysis.

From the bacterial sequences obtained, low-quality sequences and those shorter than 250 bases were omitted from further analyses, as were the suspected chimeras $(\approx 10 \%$ of the total se- quences), and eliminated from further analysis. Bacterial sequences were aligned using the Silva-compatible alignment database and a distance matrix was calculated using MOTHUR dis.seq module. Sequences were then classified into OTUs using a 97\% sequence similarity threshold. Representatives of each OTU were classified with the MOTHUR classify.seqs module, and affiliation was verified by NCBI Blast analysis. Sequences were deposited in the GenBank SRA database under accession number SRA048248 (experiment SRX109547 for bacteria and experiment SRX109548 for fungal sequences).

Statistical analyses. Soil-suppressiveness experiments were carried out independently at least twice. Separate analyses of each experiment showed homogeneous variances of the experimental error between the replicates. All treatment means were compared simultaneously by Tukey's protected test for significant differences. Statistical analyses in the presented figures show data from one representative of two experiments. Analyses were performed with SAS software (release 8.01 for PC; SAS Institute, Cary, NC) at $P \leq 0.05$. Sample coverage was estimated according to Good (22). For each sample, the Chao1 richness estimate (11) and the dominance estimate were calculated. After classification into OTUs, the count data from the different samples were Hellinger transformed, to reduce bias related to differences in the number of sequences per sample (38). The compositions were compared by non-metric multidimensional scaling based on pairwise 1-Pearson r distance matrix using STATISTICA (version 7.1) software.

\section{RESULTS}

Cucumber crown and root rot progress in suppressive versus control soils. Soil amendment with WR induced soil suppressiveness, manifested as delayed and reduced seedling wilt (Fig. 1). Crown and root rot incidence in cucumber seedlings which were inoculated with $F$. oxysporum f. sp. radicis-cucumerinum before transplanting in the WR-amended soil was significantly lower compared with nonamended soil (Fig. 1), thus confirming previous results (33). Disease symptoms (chlorosis) initiated in

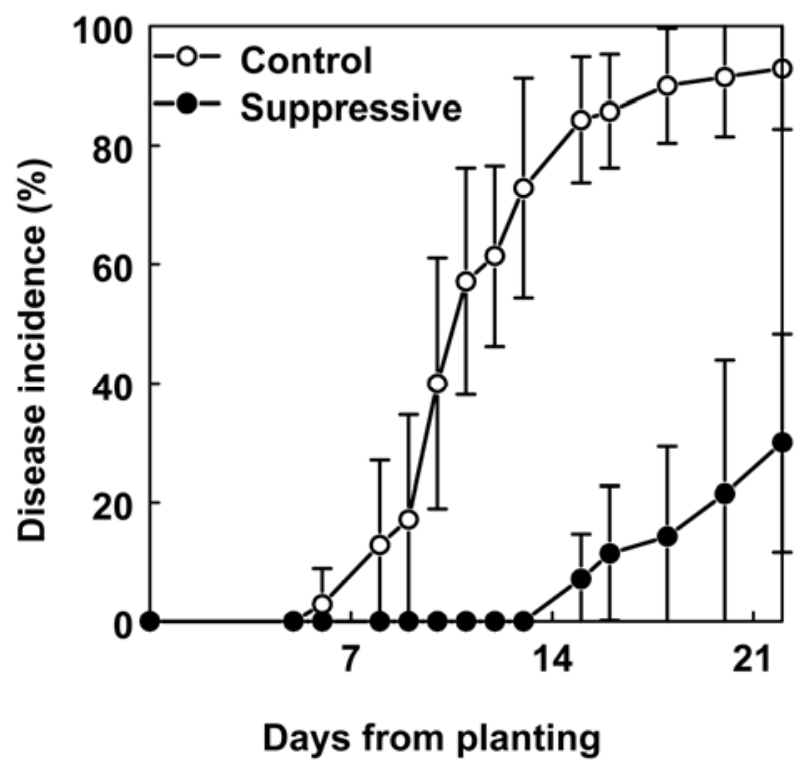

Fig. 1. Fusarium crown and root rot incidence in inoculated cucumber transplants planted in wild rocket (WR)-amended soil or control, nonamended soil. Cucumber seedlings were inoculated with macroconidia of Fusarium oxysporum f. sp. radicis-cucumerinum at $10^{5} \mathrm{CFU} / \mathrm{ml}$ and transplanted in the soil. Means and standard deviations are presented $(n=5)$. Area under the disease progress curve in the WR-amended soil (129.3) was significantly different from that of control soil $(1,019.3)$ according to Tukey's honestly significant difference test at $P<0.0001$. 
transplants in nonamended soil 6 days after inoculation and transplantation whereas, in WR-amended soil, first symptoms appeared only after 14 days.

Real-time PCR quantification of $F$. oxysporum f. sp. radiciscucumerinum in the roots 3 days after inoculation (in plants with no expressed symptoms) showed similar target numbers for both WR-amended and nonamended soils (Fig. 2A), indicating similar inoculum density in the root and infection potential. In contrast, target numbers of $F$. oxysporum f. sp. radicis-cucumerinum were significantly lower (by $66 \%, P<0.01$ ) 6 days after inoculation and transplanting in the suppressive soil, compared with the nonamended one (Fig. 2B). No F. oxysporum f. sp. radicis-cucumerinum targets were detected in control, noninoculated plants.

Impact of root inoculation by $F$. oxysporum f. sp. radiciscucumerinum and of transplantation in suppressive soil on the composition of root fungal community. Fungal colonization of cucumber roots following transplantation in the conducive or in the suppressive soils was assessed using mass sequencing. A set of 182,204 high-quality fungal ITS sequences was analyzed (Table 2). These sequences were grouped into 33 OTUs, using a 99\% sequence-similarity threshold. The fungal community was characterized by low species diversification in roots of all treatments (Table 2). This was also demonstrated by the low number of OTUs which were represented by one (singletons) or two (doubletons) sequences in all the samples examined (Table 2). Non-metric multidimensional scaling analysis (NMDS) revealed a strong effect of root inoculation with $F$. oxysporum f. sp. radicis- cucumerinum on fungal community composition in both suppressive and control soils, 3 and 6 days after inoculation and transplanting (Fig. 3). Whereas fungal communities in samples from inoculated roots were closely clustered, samples from noninoculated roots were scattered (regardless of the soil), indicating that F. oxysporum f. sp. radicis-cucumerinum inoculation was the major factor affecting the composition of the root fungal community. Neither soil type nor day of sampling was indicated as an influential factor according to the NMDS analysis, regardless of F. oxysporum f. sp. radicis-cucumerinum inoculation (Fig. 3).

Of the 33 OTUs found, 13 OTUs included over $99.7 \%$ of the sequences. These OTUs were affiliated with $F$. oxysporum, $F u$ sarium spp., Chaetomium sp., Sodaria tomento-alba, Plectosphaerella sp., Alternaria sp., Thielaviopsis basicola, and uncultured Ascomycota (Table 3). As expected, the relative abundance of sequences affiliated with $F$. oxysporum increased 10 -fold following root inoculation with $F$. oxysporum f. sp. radicis-cucumerinum, whereas the relative abundances of the other major groups (Fusarium sp. 14005 and Chaetomium sp. 15003) were reduced. Factorial analysis demonstrated that the relative abundances of these major groups, which were highly affected by root inoculation with $F$. oxysporum f. sp. radiciscucumerinum $(P<0.001)$, were not affected by WR amendment or day of sampling. The trend of reduction in relative abundance following $F$. oxysporum f. sp. radicis-cucumerinum inoculation was similar for additional detected fungal OTUs (Table 3). A significant effect of WR amendment on relative abundance was

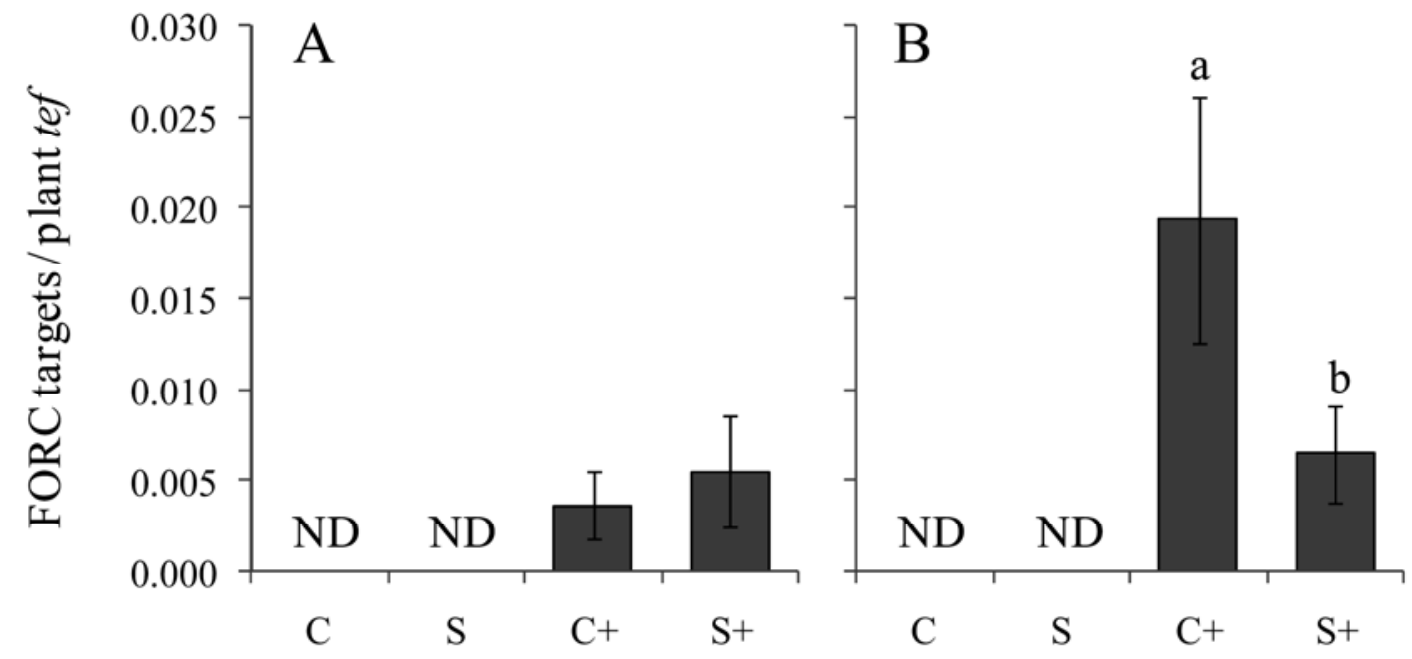

Fig. 2. Quantification of Fusarium oxysporum f. sp. radicis-cucumerinum (FORC) in roots of cucumber grown for A, 3 or B, 6 days in wild rocket-amended, suppressive soil (S) or control soil (C). Seedlings were inoculated with macroconidia of F. oxysporum f. sp. radicis-cucumerinum at $10^{5} \mathrm{CFU} / \mathrm{ml}(+)$, or noninoculated, before transplanting. F. oxysporum f. sp. radicis-cucumerinum was quantified using a specific primer pair and normalized using the reference plant tef gene. ND: not detected. Different letters indicate significant differences between the means according to Kruskal-Wallis analysis of variance at $P<0.01$.

TABLE 2. Analysis of fungal community structure based on mass sequencing of fungal internal transcribed spacer gene fragments ${ }^{\mathrm{w}}$

\begin{tabular}{llccccc}
\hline Day & \multicolumn{1}{c}{ Soil } & Fusarium $^{\mathrm{x}}$ & $\Sigma$ Sequences $^{\mathrm{y}}$ & Number of 99\% OTUs $^{\mathrm{z}}$ & Singletons $^{\text {Doubletons }}$ \\
\hline 3 & Control & - & 9,112 & $9 \pm 3$ & $0.6 \pm 0.5$ & $1.0 \pm 1$ \\
3 & Suppressive & - & 11,315 & $9 \pm 3$ & $1.2 \pm 1.6$ & $1.4 \pm 1.1$ \\
3 & Control & + & 17,962 & $9 \pm 2$ & $1.25 \pm 1.5$ & $0.7 \pm 0.5$ \\
3 & Suppressive & + & 19,989 & $14 \pm 1$ & $2.2 \pm 0.8$ & $0.75 \pm 0.5$ \\
6 & Control & - & 17,071 & $11 \pm 2$ & $1.4 \pm 0.9$ & $1.2 \pm 0.8$ \\
6 & Suppressive & - & 22,325 & $8 \pm 2$ & $2.2 \pm 1.8$ & $0.8 \pm 1.3$ \\
6 & Control & + & 46,100 & $7 \pm 2$ & $2.0 \pm 2.0$ & $0.2 \pm 0.4$ \\
6 & Suppressive & + & 38,330 & & & \\
\hline
\end{tabular}

${ }^{\mathrm{w}}$ Coverage and diversity indices were calculated for the different samples after classification of the sequence data at the genus level. Means and standard deviations $(n=5)$ are presented.

${ }^{x}$ Cucumber seedlings were inoculated with macroconidia of Fusarium oxysporum f. sp. radicis-cucumerinum at $10^{5} \mathrm{CFU} / \mathrm{ml}(+)$, or noninoculated (-), before transplanting.

${ }^{\mathrm{y}}$ Number of sequences. Coverage estimates, calculated after Good (21), were $>99.9 \%$ for all samples. $\mathrm{C}_{\mathrm{Good}}=1-\mathrm{F} 1 / \mathrm{N}, \mathrm{F} 1=$ number of singletons, and $\mathrm{N}=$ number of sequences.

z Operational taxonomic units (OTUs); classification using 99\% similarity threshold. 
observed for less-abundant OTUs $(P<0.05)$, where either WRrelated reduction or increase were found.

Impact of root inoculation with $F$. oxysporum $\mathbf{f}$. sp. radiciscucumerinum and transplantation in suppressive soil on root colonization by bacteria. Real-time quantitative PCR revealed no significant differences in the abundance of total bacteria associated with cucumber roots 3 and 6 days after transplantation in suppressive or control soils, regardless of $F$. oxysporum f. sp. radicis-cucumerinum inoculation (Table 4).

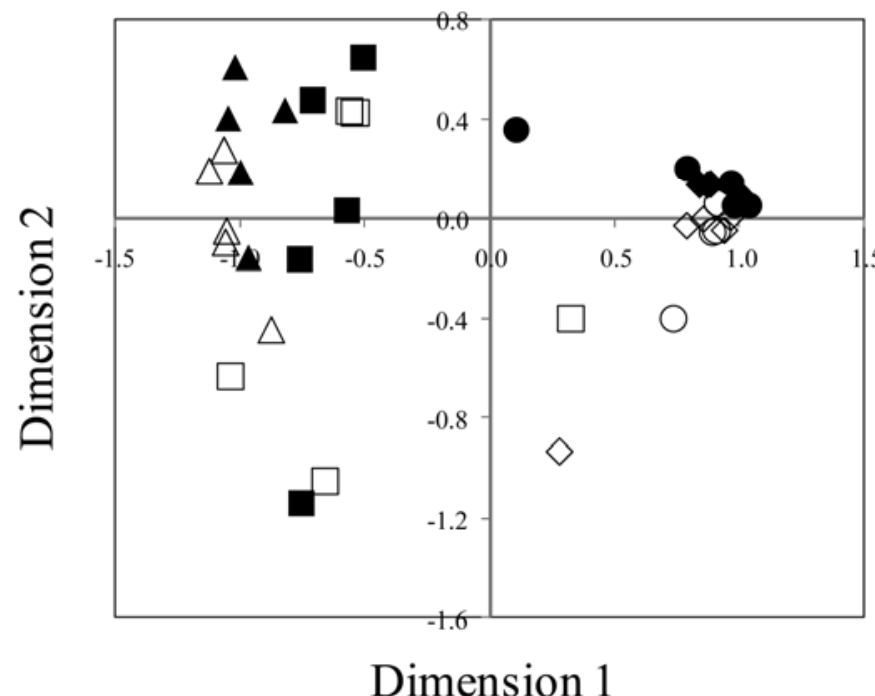

Fig. 3. Comparison of root-associated fungal community based on mass sequencing of ribosomal internal transcribed spacer by 454-pyrosequencing. Fungal community composition was determined for cucumber roots grown for 3 (open symbols) or 6 (filled symbols) days after inoculation with macroconidia of Fusarium oxysporum $\mathrm{f}$. sp. radicis-cucumerinum at $10^{5} \mathrm{CFU} / \mathrm{ml}$ or noninoculation, and transplantation in $\mathbf{\square}$, control soil; $\mathbf{\Delta}$, wild rocketamended soil; $\diamond$, control soil $+F$. oxysporum $\mathrm{f}$. sp. radicis-cucumerinum; and - wild rocket-amended soil $+F$. oxysporum f. sp. radicis-cucumerinum. Sequences were classified into operational taxonomic units using a $99 \%$ similarity threshold. After Hellinger transformation of the count data, a 1Pearson $r$ distance matrix between the different samples was calculated. The matrix was used for nonmetric multidimensional scaling analysis by STATISTICA. The first and second dimensions are presented for the complete data set $($ Stress $=0.065)$.
Mass sequencing of bacterial 16S rRNA gene fragments showed a high diversity of bacteria associated with the roots. Based on a data set of 81,731 high-quality sequences, 3,490 OTUs were defined using a $97 \%$ sequence-similarity threshold, which were affiliated with 792 genera. Based on genus classification, root inoculation with F. oxysporum f. sp. radicis-cucumerinum significantly increased the taxonomic richness (Chaol estimate) and moderately reduced community dominance levels 3 days after transplantation in both nonamended and suppressive soils (Table 5). This effect continued to 6 days after transplantation in the nonamended soil. In contrast, a sharp decrease in the dominance levels of bacterial communities was evident 6 days after transplantation in the suppressive soil, regardless of $F$. oxysporum $\mathrm{f}$. sp. radicis-cucumerinum inoculation (Table 5). Comparative analysis of root bacterial community compositions revealed divergence in root assemblages from nonamended and suppressive soils 6 days after transplantation (Fig. 4).

The effect of $F$. oxysporum f. sp. radicis-cucumerinum inoculation on bacterial community composition only became apparent 6 days after transplantation. Proteobacteria were the dominant bacterial phylum colonizing the cucumber roots ( 75 to $93 \%$ of the sequences in all treatments) (Table 6). Among the Proteobacteria, $\beta$-proteobacteria and $\alpha$-proteobacteria were the most dominant (19 to $73 \%$ and 11 to $46 \%$, respectively). Suppressive soil significantly altered the relative abundance of the dominant bacterial groups due to a reduction in Massilia spp. ( $\beta$-proteobacteria), the single most dominant genus in the data set $(P<0.05)$, compared with the root-associated bacteria from nonamended soil (Table 6). After 6 days, the relative abundance of root-associated Massilia spp. was four to five times lower in the WR-amended, suppressive soil relative to nonamended soils. The relative abundance of Massilia spp. in the $F$. oxysporum f. sp. radicis-cucumerinum-inoculated roots was further reduced in the suppressive soil plants $(P<0.05)$. In contrast, the relative abundance of Rhizobium and Devosia spp. and other $\alpha$-proteobacteria in the roots significantly increased in suppressive soil compared with the nonamended one $(P<0.05)$.

Quantitative analysis of root-associated Massilia spp. revealed one order of magnitude lower abundance on roots of suppressive soil, compared with nonamended soil, after 6 days of growth (Table 4). These quantitative real-time PCR results were consistent with those obtained by mass sequencing.

The relative abundance of root-associated actinobacteria, including Streptomyces spp., was significantly higher in suppres-

TABLE 3. Composition and relative abundance of fungi associated with cucumber roots, in control (C) and suppressive (S) soils, as affected by Fusarium oxysporum $\mathrm{f}$. sp. radicis-cucumerinum inoculation at $10^{5} \mathrm{CFU} / \mathrm{ml}(+)^{\mathrm{x}}$

\begin{tabular}{|c|c|c|c|c|c|c|c|c|c|}
\hline \multirow[b]{2}{*}{ Taxonomy ${ }^{\mathrm{y}}$} & \multirow[b]{2}{*}{ NCBI relative ${ }^{\mathrm{z}}$} & \multicolumn{4}{|c|}{3 days } & \multicolumn{4}{|c|}{6 days } \\
\hline & & $\mathrm{C}$ & $\mathrm{S}$ & $\mathrm{C}+$ & $\mathrm{S}+$ & $\mathrm{C}$ & $\mathrm{S}$ & $\mathrm{C}+$ & $\mathrm{S}+$ \\
\hline$F$, oxysporum (Hypocreales) a & JF440593; 99\% & 15.9 & 2.4 & 82.7 & 89.6 & 11.0 & 3.5 & 95.3 & 87.1 \\
\hline Fusarium sp. 14005 (Hypocreales) a & EU750680; 99\% & 40.8 & 64.2 & 2.5 & 1.9 & 51.8 & 71.7 & 4.3 & 10.0 \\
\hline Fusarium sp. (Hypocreales) a,b,d & AY729051; $99 \%$ & ND & 2.3 & ND & $>0.1$ & 0.3 & 3.8 & $>0.1$ & $>0.1$ \\
\hline Thielaviopsis basicola (Microascales) & GQ131878;99\% & 1.9 & $>0.1$ & $>0.1$ & $>0.1$ & 1.8 & $>0.1$ & $>0.1$ & $>0.1$ \\
\hline Chaetomium sp. 15003 (Sordariales) a,c & EU750691; $98 \%$ & 25.9 & 22.6 & 12.6 & 5.9 & 16.3 & 9.2 & 0.2 & 0.4 \\
\hline Sordaria tomento-alba (Sordariales) & AY681195; 100\% & 6.3 & 1.6 & $>0.1$ & $>0.1$ & 11.1 & ND & ND & ND \\
\hline Plectosphaerella sp. (Phyllachorales) & FJ196603; 99\% & ND & ND & ND & $>0.1$ & 0.9 & $>0.1$ & $>0.1$ & $>0.1$ \\
\hline Alternaria sp. (Pleosporales) & FJ210489; $100 \%$ & 3.0 & $>0.1$ & $>0.1$ & ND & 0.2 & $>0.1$ & ND & ND \\
\hline Uncultured Ascomycota $\mathrm{a}, \mathrm{b}$ & EU437434; $99 \%$ & 2.9 & 6.3 & 1.2 & 2.2 & 4.1 & 10.1 & 0.1 & 2.3 \\
\hline Uncultured endophytic fungus & FJ524302; 88\% & ND & 0.2 & 0.4 & ND & $>0.1$ & 0.8 & $>0.1$ & $>0.1$ \\
\hline Uncultured Ascomycota a,b,d & EU489987; $93 \%$ & 0.7 & $>0.1$ & $>0.1$ & ND & 1.3 & $>0.1$ & $>0.1$ & $>0.1$ \\
\hline Uncultured Ascomycota & HM162273; 96\% & 0.6 & ND & ND & ND & ND & ND & ND & ND \\
\hline Unclassified fungus & GU078645; 94\% & 1.4 & $>0.1$ & $>0.1$ & $>0.1$ & 0.3 & 0.5 & $>0.1$ & $>0.1$ \\
\hline Others & $\ldots$ & 0.7 & 0.3 & 0.3 & 0.4 & 0.8 & 0.3 & $>0.1$ & $>0.1$ \\
\hline
\end{tabular}

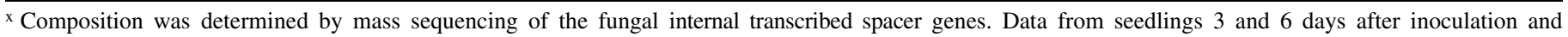
transplantation is presented. Mean relative abundances of the dominant operational taxonomic units $(99 \%$ similarity threshold $)$ are presented. Symbols: $+=F$. oxysporum $\mathrm{f}$. sp. radicis-cucumerinum inoculation at $10^{5} \mathrm{CFU} / \mathrm{ml}, \mathrm{C}=$ control soil, $\mathrm{S}=$ suppressive soil, and $\mathrm{ND}=$ not detected.

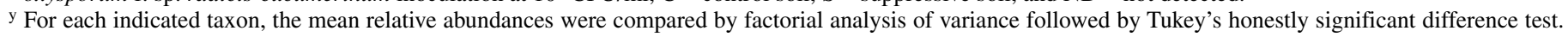
Letters indicate significant differences $(P<0.05)$ between the factors: F. oxysporum f. sp. radicis-cucumerinum (a), soil (b), day (c), F. oxysporum f. sp. radiciscucumerinum $\times$ soil $(\mathrm{d})$.

z NCBI = National Center for Biotechnology Information . 
sive versus nonamended soil, with no significant effect of $F$. oxysporum f. sp. radicis-cucumerinum inoculation (Table 6). Three days after transplantation, the number of Streptomyces spp., which was the dominant taxon in the actinobacteria, was significantly higher in the suppressive versus nonamended soil (Table 4). However, its quantity in the roots of F. oxysporum f. sp. radicis-cucumerinum-inoculated transplants decreased significantly after 6 days compared with the noninoculated transplants in the nonamended soil (Table 4).

The relative abundance of members of the Firmicutes, namely, Bacillus and Paenibacillus spp., also increased in the suppressive soils compared with the nonamended soils for both 3- and 6-dayold transplants.

Root infection with $F$. oxysporum f. sp. radicis-cucumerinum significantly affected the relative abundance of some bacterial taxons. For example, the genus Mitsuaria ( $\beta$-proteobacteria) was detected almost exclusively in $F$. oxysporum f. sp. radicis-cucumerinum-inoculated nonamended soil and the relative abundance of Methylophilus spp. ( $\beta$-proteobacteria) increased following $F$. oxysporum f. sp. radicis-cucumerinum inoculation, regardless of soil type (Table 6).

Composition of root-associated Streptomyces spp. The relative abundance of root-associated Streptomyces spp. increased in the suppressive soils compared with the nonamended soils as early as 3 days post $F$. oxysporum f. sp. radicis-cucumerinum inoculation and transplantation (Table 6). A significant shift in composition of the root-associated Streptomyces populations between control and suppressive soils was found 6 days after transplantation according to PCR-DGGE analysis (Fig. 5). In contrast, $F$. oxysporum f. sp. radicis-cucumerinum inoculation had no visible effect on the community fingerprint, in either suppressive or nonamended soils. Similar results were found in roots 3 days after transplantation (Fig. 6). The difference between root Streptomyces community fingerprints in WR-amended and nonamended soils was mainly attributed to a dominant band (Figs. 5 and 6, marked with arrow) that appeared in all samples from WRamended soil. This band also appeared in some samples from nonamended soil but, in most of them, at much lower intensity. Sequence analysis of this band was performed for eight excised bands representing all of the treatments. All obtained sequences were identical and were $99.9 \%$ similar to the Streptomyces humidus-related population (HQ607425) according to NCBI Blast analysis.

\section{DISCUSSION}

Soil suppressiveness to root diseases evolves following amendment with WR and is sustainable, even after repeated inoculations with the pathogen in the plant-soil system (33). This suppressiveness was further verified and validated in the current study (Fig. 1). Disease suppression was maintained for 21 days after $F$. oxysporum f. sp. radicis-cucumerinum inoculation of cucumber seedlings and transplanting into the WR-amended soil. Delayed disease onset and reduced symptom expression in the suppressive soil were noticeable as early as 6 days postinoculation. Therefore, we hypothesize that the impact of soil suppressiveness on root infection by $F$. oxysporum $\mathrm{f}$. sp. radicis-cucumerinum and disease development begins after root inoculation by the pathogen. This impact may involve direct suppression of fungal survival and growth, or an indirect effect via shifts in the microbial population and assembly in the rhizosphere and roots.

Quantitative assessment of $F$. oxysporum f. sp. radicis-cucumerinum in the cucumber roots indicated that the initial infection units of the pathogen were not affected by the suppressive soil 3 days after seedling inoculation and transplanting (Fig. 2). However, after an additional 3 days, the buildup of pathogen population in the roots of plants in control, nonamended soil was

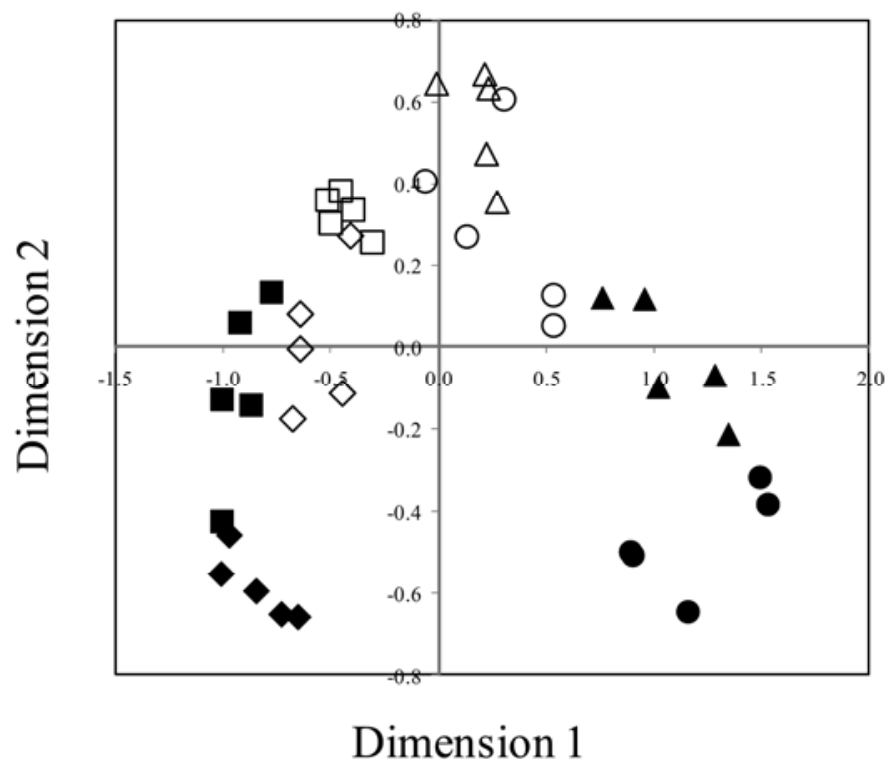

Fig. 4. Comparison of the bacterial community composition on roots based on mass sequencing of bacterial $16 \mathrm{~S}$ rRNA gene fragments. Bacterial community composition was determined for cucumber roots grown for 3 (open symbols) or 6 (filled symbols) days after inoculation with macroconidia of Fusarium oxysporum $\mathrm{f}$. sp. radicis-cucumerinum at $10^{5} \mathrm{CFU} / \mathrm{ml}$, or noninoculation, and transplantation in $\mathbf{\square}$, control soil; $\mathbf{\Delta}$, suppressive soil; $\boldsymbol{\bullet}$, control soil + F. oxysporum f. sp. radicis-cucumerinum inoculation; and $\bigcirc$, suppressive soil $+F$. oxysporum f. sp. radicis-cucumerinum inoculation. Sequences were classified into operational taxonomic units using a $97 \%$ similarity threshold. After Hellinger transformation of the count data, a 1-Pearson $r$ distance matrix between the different samples was calculated. The matrix was used for nonmetric multidimensional scaling analysis by STATISTICA (Stress = $0.038)$. The first and second dimensions are presented.

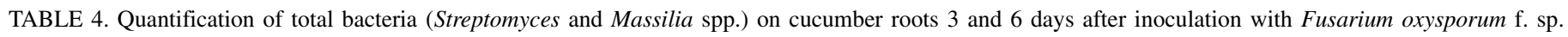
radicis-cucumerinum (Fusarium) and transplantation ${ }^{\mathrm{z}}$

\begin{tabular}{|c|c|c|c|c|c|}
\hline \multirow[b]{2}{*}{ Day } & \multirow[b]{2}{*}{ Soil } & \multirow[b]{2}{*}{ Fusarium } & \multicolumn{3}{|c|}{ Log targets/plant tef } \\
\hline & & & Total bacteria & Streptomyces & Massilia \\
\hline 3 & Control & - & $2.14 \pm 0.16$ & $-0.18 \pm 0.18 b$ & $1.40 \pm 0.20$ \\
\hline 3 & Suppressive & - & $2.20 \pm 0.29$ & $0.20 \pm 0.22 \mathrm{a}$ & $1.09 \pm 0.25$ \\
\hline 3 & Control & + & $1.96 \pm 0.37$ & $0.08 \pm 0.11 \mathrm{ab}$ & $1.41 \pm 0.43$ \\
\hline 3 & Suppressive & + & $1.88 \pm 0.78$ & $0.28 \pm 0.29 \mathrm{a}$ & $0.96 \pm 0.79$ \\
\hline 6 & Control & - & $2.25 \pm 0.79$ & $1.79 \pm 0.44 \mathrm{a}$ & $2.20 \pm 0.45 \mathrm{a}$ \\
\hline 6 & Suppressive & - & $2.24 \pm 0.16$ & $1.42 \pm 0.13 \mathrm{ab}$ & $0.78 \pm 0.36 b$ \\
\hline 6 & Control & + & $2.54 \pm 0.14$ & $1.53 \pm 0.22 \mathrm{ab}$ & $2.06 \pm 0.23 \mathrm{a}$ \\
\hline 6 & Suppressive & + & $2.36 \pm 0.19$ & $1.23 \pm 0.09 \mathrm{~b}$ & $0.58 \pm 0.45 b$ \\
\hline
\end{tabular}

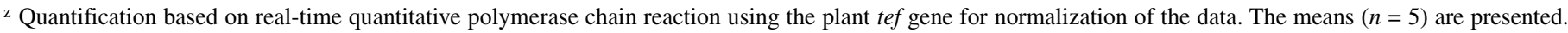
Means were compared by factorial analysis of variance. Only statistically significant sources and interactions are indicated. Different letters in a column indicate significant differences at $P<0.05$. 
TABLE 5. Analysis of bacterial community structure based on mass sequencing of $16 \mathrm{~S}$ rRNA gene fragments ${ }^{\mathrm{q}}$

\begin{tabular}{|c|c|c|c|c|c|c|c|c|c|}
\hline \multirow[b]{2}{*}{ Day } & \multirow[b]{2}{*}{ Soil } & \multirow[b]{2}{*}{ Fusarium $^{\mathrm{r}}$} & \multirow[b]{2}{*}{$\Sigma$ Sequences $^{\mathrm{s}}$} & \multirow[b]{2}{*}{$97 \% \mathrm{OTUs}^{\mathrm{t}}$} & \multirow[b]{2}{*}{ Genera } & \multirow[b]{2}{*}{ Coverage $^{\mathrm{u}, \mathrm{v}}$} & \multicolumn{3}{|c|}{ Diversity indices ${ }^{w}$} \\
\hline & & & & & & & $\mathrm{Chao1}^{\mathrm{v}, \mathrm{x}}$ & Dominance $^{y}$ & $\mathrm{H}^{\prime \mathrm{z}}$ \\
\hline 3 & Control & - & 11,260 & $524 \pm 54$ & $116 \pm 16$ & 0.979 & 173 & 0.285 & 2.38 \\
\hline 3 & Suppressive & - & 7,967 & $466 \pm 63$ & $122 \pm 16$ & 0.968 & 189 & 0.205 & 2.79 \\
\hline 3 & Suppressive & + & 11,872 & $472 \pm 36$ & $145 \pm 17$ & 0.977 & 200 & 0.129 & 3.13 \\
\hline 6 & Control & - & 12,246 & $572 \pm 54$ & $158 \pm 13$ & 0.975 & 222 & 0.266 & 2.67 \\
\hline 6 & Suppressive & - & 5,917 & $429 \pm 76$ & $135 \pm 10$ & 0.974 & 206 & 0.071 & 3.52 \\
\hline
\end{tabular}

${ }^{\mathrm{q}}$ Coverage and diversity indices were calculated for the different samples after classification of the sequence data at the genus level. Means and standard deviations $(n=5)$ are presented for coverage, richness, dominance, and Shannon $\mathrm{H}^{\prime}$ diversity estimators.

${ }^{\mathrm{r}}$ Cucumber seedlings were inoculated with macroconidia of Fusarium oxysporum f. sp. radicis-cucumerinum at $10^{5} \mathrm{CFU} / \mathrm{ml}(+)$, or noninoculated (-), before transplanting.

s Number of sequences.

t OTUs = operational taxonomic units.

"Sample coverage estimate calculated after Good (22): $\mathrm{C}_{\mathrm{Good}}=1-\mathrm{F} 1 / \mathrm{N} ; \mathrm{F} 1=$ number of singletons and $\mathrm{N}=$ number of sequences.

${ }^{v}$ No significant differences according to analysis of variance and Tukey's honestly significant difference test $(P=0.05)$.

${ }^{\mathrm{w}}$ Chao1 taxa richness estimate (11).

${ }^{x}$ Neuman-Keuls critical range: $\mathrm{Chaol}=43$, Dominance $=0.071$, and $\mathrm{H}^{\prime}=0.37$.

y Dominance $\mathrm{D}=\Sigma\left[\left(n_{i} / N\right)^{2}\right] ; n_{i}=$ number of sequences assigned to the $i$ th genus.

${ }^{\mathrm{z}}$ Shannon $\mathrm{H}^{\prime}$ index of diversity $\mathrm{H}^{\prime}=-\Sigma \mathrm{p} i \times \ln (\mathrm{p} i)$; $\mathrm{p} i=$ relative abundance of the $i$ th genus.

TABLE 6. Composition and relative abundance (\%) of the major taxonomic groups identified in cucumber root bacterial communities by mass sequencing of $16 \mathrm{~S}$ rRNA gene fragments by 454-pyrosequencing ${ }^{\mathrm{x}}$

\begin{tabular}{|c|c|c|c|c|c|c|c|c|}
\hline \multirow[b]{3}{*}{ Taxonomy ${ }^{y}$} & \multicolumn{4}{|c|}{3 days } & \multicolumn{4}{|c|}{6 days } \\
\hline & \multicolumn{2}{|c|}{ Null } & \multicolumn{2}{|c|}{ Fusarium } & \multicolumn{2}{|c|}{ Null } & \multicolumn{2}{|c|}{ Fusarium } \\
\hline & $\mathrm{C}$ & $\mathrm{S}$ & $\mathrm{C}$ & $\mathrm{S}$ & $\mathrm{C}$ & $\mathrm{S}$ & $\mathrm{C}$ & $\mathrm{S}$ \\
\hline$\beta$-Proteobacteria & 69.0 & 56.7 & 64.3 & 45.2 & 73.3 & 21.9 & 61.3 & 19.3 \\
\hline Massilia a,b,c,d & 51.9 & 42.5 & 41.0 & 28.3 & 50.7 & 12.5 & 34.3 & 6.7 \\
\hline Janthinobacterium a,b,d & 1.7 & 0.8 & 2.1 & 0.3 & 4.2 & 0.3 & 4.5 & 0.5 \\
\hline Methylophilus c & 1.6 & 1.8 & 2.5 & 2.8 & 1.5 & 0.9 & 3.2 & 4.0 \\
\hline Thauera a,b,c,d,f,g & 0.1 & 0.3 & 0.1 & 0.2 & $<0.1$ & 0.2 & 0.7 & 1.5 \\
\hline$\alpha$-Proteobacteria $\alpha$ & 20.8 & 23.3 & 21.1 & 33.3 & 10.7 & 43.2 & 19.6 & 45.8 \\
\hline Rhizobium a,b,d & 7.2 & 9.8 & 6.0 & 10.3 & 4.3 & 17.1 & 7.0 & 16.6 \\
\hline Brevundimonas b,c,g & 4.2 & 2.9 & 3.4 & 6.1 & 0.9 & 4.4 & 4.2 & 6.1 \\
\hline Devosia a,b,d & 0.7 & 2.3 & 0.6 & 2.4 & 0.3 & 6.0 & 0.3 & 4.9 \\
\hline Shinella_genera a,b,d & 0.4 & 1.5 & 0.5 & 0.9 & 0.3 & 4.5 & 0.4 & 5.3 \\
\hline Mesorhizobium b,d & 1.3 & 1.5 & 1.1 & 1.4 & 0.9 & 1.9 & 0.8 & 1.9 \\
\hline Cellvibrio & $<0.1$ & 0.1 & $<0.1$ & 0.4 & 0.2 & 2.8 & $<0.1$ & 2.3 \\
\hline Colwellia a,b,d & 0.2 & 0.6 & 0.2 & 0.6 & $<0.1$ & 1.5 & 0.2 & 1.8 \\
\hline Stenotrophomonas c,f & 0.2 & 0.3 & 0.1 & 0.4 & 0.2 & 0.2 & 0.7 & 1.1 \\
\hline Bacteroidetes & 2.5 & 2.8 & 4.7 & 2.7 & 4.7 & 4.2 & 10.8 & 5.6 \\
\hline Chryseobacterium b,c,e & 0.1 & $<0.1$ & 0.7 & $<0.1$ & 0.2 & ND & 5.5 & ND \\
\hline Chitinophagaceae a,b & 1.7 & 0.7 & 2.3 & 0.8 & 3.4 & 1.0 & 4.6 & 2.0 \\
\hline Flavisolibacter $\mathrm{a}, \mathrm{b}, \mathrm{d}$ & 0.1 & $<0.1$ & 0.2 & $<0.1$ & 1.2 & 0.3 & 0.8 & 0.4 \\
\hline Sphingobacterium b & 0.5 & 0.9 & 0.9 & 0.8 & 0.4 & 1.1 & 0.3 & 1.0 \\
\hline Actinobacteria & 2.6 & 4.6 & 3.4 & 4.3 & 3.5 & 9.6 & 1.4 & 4.8 \\
\hline Streptomyces a,b,d & 0.4 & 2.0 & 1.2 & 2.4 & 1.9 & 6.2 & 0.6 & 2.6 \\
\hline Firmicutes & 1.1 & 5.7 & 1.4 & 4.3 & 2.1 & 8.5 & 1.4 & 9.7 \\
\hline Bacillus b & $<0.1$ & 1.53 & $<0.1$ & 1.2 & ND & 1.0 & ND & 1.0 \\
\hline Paenibacillus a,b,d & 0.5 & 2.0 & 0.8 & 1.8 & 1.6 & 5.9 & 0.7 & 7.6 \\
\hline Planococcaceae b & $<0.1$ & 1.1 & $<0.1$ & 0.5 & ND & 0.9 & ND & 0.7 \\
\hline
\end{tabular}

${ }^{\mathrm{x}}$ Noninoculated (Null) and Fusarium oxysporum f. sp. radicis-cucumerinum (Fusarium) inoculation at $10^{5} \mathrm{CFU} / \mathrm{ml}$; C = control soil and $\mathrm{S}=$ suppressive soil. $\mathrm{ND}=$ not detected.

y For each indicated taxon, the mean relative abundances were compared by factorial analysis of variance followed by Tukey's honestly significant difference test. Letters indicate significant differences $(P<0.05)$ between the factors day (a), soil (b), F. oxysporum f. sp. radicis-cucumerinum (c), day $\times$ soil $(\mathrm{d})$, soil $\times F$. oxysporum f. sp. radicis-cucumerinum (e), day $\times F$. oxysporum f. sp. radicis-cucumerinum (f), and day $\times$ soil $\times F$. oxysporum $\mathrm{f}$. sp. radicis-cucumerinum $(\mathrm{g})$.

${ }^{z}$ Combination of phyla in which the total taxonomic groups detected had relative abundance $<1 \%$. 
three times higher than in the suppressive soil. This suggests that the suppressive soil itself does not initially directly reduce the number of pathogen propagules or their capacity to colonize the roots. It also emphasizes that disease suppressiveness is associated with the root zone, with the presence of both pathogen and host, under suppressive conditions $(58,61)$.

Soil suppressiveness to root diseases may result from specific antagonism to the pathogen. For example, soils that are naturally suppressive to Fusarium wilt have been well documented $(64,71)$ : they are characterized by competition for niche and nutrients that is closely related to saprophytic, nonpathogenic species of Fusarium (71) and the activity of native protective $F$. oxysporum strains and Pseudomonas spp. $(2,18)$. In the roots of cucumber transplants, native Fusarium spp. constituted the dominant root fungal population in all tested soils, regardless of previous soil treatment (suppressive or not) or transplant inoculation with $F$. oxysporum f. sp. radicis-cucumerinum (Table 3). This dominance of saprophytic Fusarium spp. did not, however, interfere with soil or root receptivity to $F$. oxysporum $\mathrm{f}$. sp. radicis-cucumerinum, as reflected by its pronounced colonization of the roots and disease severity of plants in the nonamended soil (Fig. 1). Moreover, the root-associated fungal community composition was not affected by the suppressive soil during the time intervals examined $(P>$ $0.05)$. However, $F$. oxysporum f. sp. radicis-cucumerinum inoculation increased the relative abundance of $F$. oxysporum in roots from 3 to 14 to 88 to $89 \%$ in WR-amended as well as nonamended soils (Fig. 3; Table 3). Hence, mechanisms other than the presence of protective nonpathogenic Fusarium spp. play a more important role in disease suppressiveness in WR-amended soil.

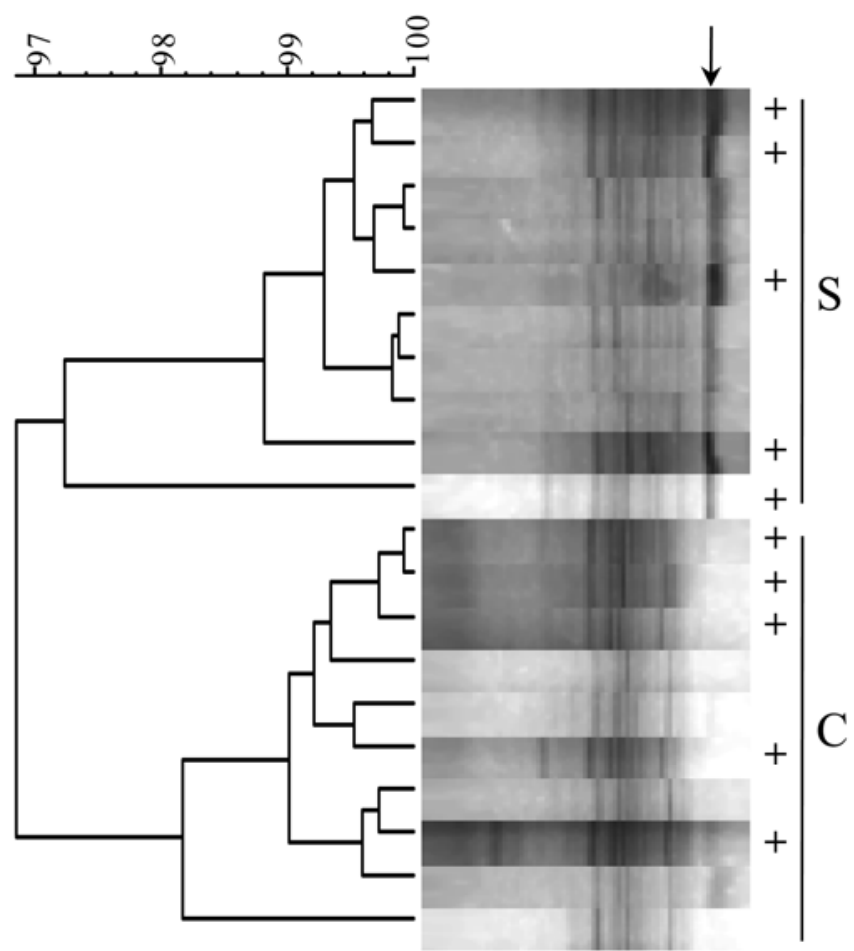

Fig. 5. Community fingerprint of root Streptomyces spp. in cucumber seedlings 6 days after transplantation into suppressive soil (S) compared with control soil (C). Cucumber seedlings were inoculated with macroconidia of Fusarium oxysporum f. sp. radicis-cucumerinum at $10^{5} \mathrm{CFU} / \mathrm{ml}(+)$, or noninoculated before planting. Streptomyces community compositions were compared based on polymerase chain reaction denaturing gradient gel electrophoresis (PCR-DGGE) patterns of 16S rRNA gene fragments amplified with a Streptomyces-specific primer pair. PCR-DGGE patterns were analyzed using Fingerprint II software. An unweighted pair-group method with arithmetic means tree was calculated from cosine correlation distance matrix. The arrow indicates bands corresponding to Streptomyces populations identified by sequence analysis of excised bands.
The evolution of soil suppressiveness has been related to shifts in the soil- and root-associated microbiome $(18,47)$. In many cases, soil suppressiveness is biologically derived from shifts in the bacterial balance in the rhizosphere, including its density and functional diversity $(41,58,75)$. Indeed, the composition of the fungal community in the root zone was not affected in the suppressive soils during our study $(P>0.05)$. Moreover, it has been suggested that consortia of microorganisms and mechanisms, rather than a single group, are involved in disease suppressiveness $(44,49,63)$. Therefore, the WR-mediated suppression of $F$. oxysporum f. sp. radicis-cucumerinum development observed in infected roots 6 days post inoculation seems to be associated with changes in root bacterial community properties.

Quantitative analysis and mass-sequencing methods indicated that the shift in bacterial communities in suppressive soil is qualitative (i.e., a shift in the composition of the bacterial community rather than in the total number of bacteria) (Table 4; Fig. 4). Previous studies have positively correlated density of cultivable heterotrophic bacterial populations with soil suppressiveness (7). Our finding, however, is based on a quantitative assessment that was not affected by the bias of cultivable heterotrophy; therefore, the suppression mechanism may stem from the interaction with more groups of microorganisms.

Bacterial community composition and structure in the rhizosphere and root have been previously associated with suppressiveness $(6,9,25)$. In our study, an increase in diversity of the root bacterial communities was evident in the suppressive soil (Table 5). However, an increase in the diversity of the bacterial community also characterized roots as a response to $F$. oxysporum $\mathrm{f}$. sp. radicis-cucumerinum inoculation, prior to the appearance of disease symptoms (3 days). Postma et al. (57) found that quali-

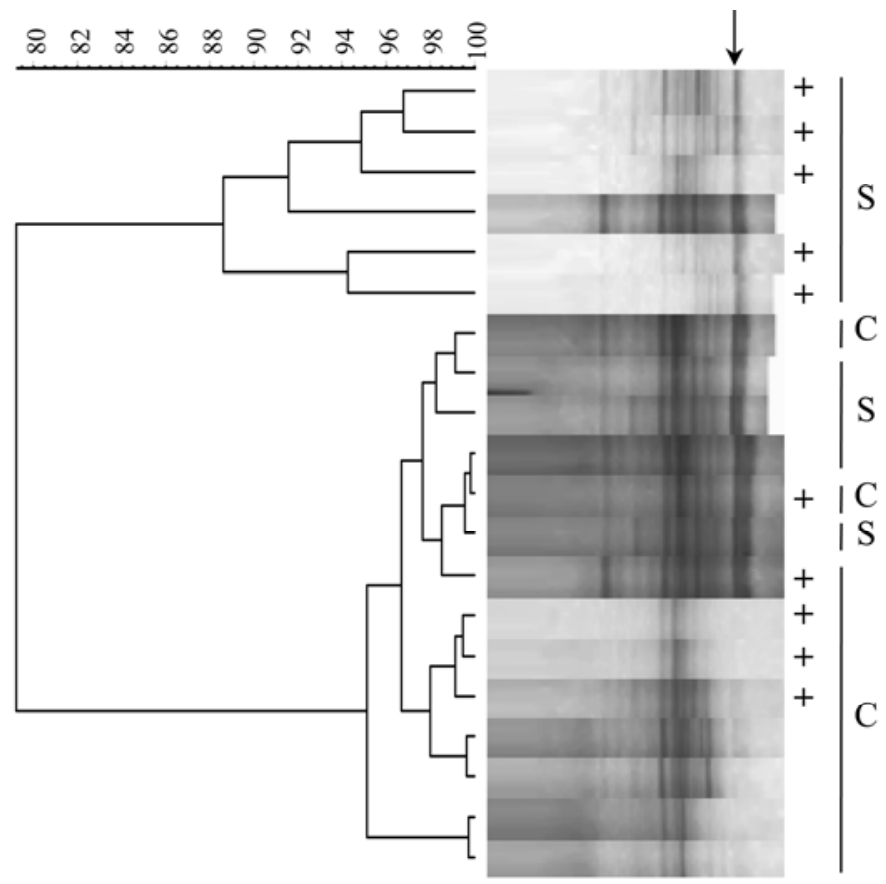

Fig. 6. Community fingerprint of root Streptomyces spp. in cucumber seedlings 3 days after transplantation into suppressive soil (S) compared with control soil (C). Cucumber seedlings were inoculated with macroconidia of Fusarium oxysporum f. sp. radicis-cucumerinum at $10^{5} \mathrm{CFU} / \mathrm{ml}(+)$, or noninoculated before planting. Streptomyces community compositions were compared based on polymerase chain reaction denaturing gradient gel electrophoresis (PCR-DGGE) patterns of 16S rRNA gene fragments amplified with a Streptomyces-specific primer pair. PCR-DGGE patterns were analyzed using the Fingerprint II software. An unweighted pair-group method with arithmetic means tree was calculated from cosine correlation distance matrix. The arrow indicates bands corresponding to Streptomyces populations identified by sequence analysis of excised bands. 
tative rather than quantitative shifts in the bacterial community correlate with disease suppressiveness. Moreover, disease suppression has been correlated with increased soil $(21,43,68)$ and endophytic (62) bacterial diversity. Yang et al. (74) also reported increased bacterial diversity on Phytophthora spp.-infected avocado roots compared with healthy ones. Therefore, it is still unknown whether an increase in root community diversity is, in itself, indicative of a suppressive process.

A sharp reduction in the population of Massilia spp. ( $\beta$ proteobacteria) in the root bacterial community (Tables 4 and 6) was the key determinant of the observed structural changes in root bacterial communities in suppressive soil (Table 5). Members of this genus, first isolated from clinical samples, are characterized as gram-negative, aerobic, flagellated, and non-spore-forming rods $(30,37)$. Massilia spp. have been detected in the rhizosphere of a variety of plant species $(1,14,24,27)$, including cucumber $(23,53,54)$. Massilia spp. have been found to exhibit exceptional dominance in cucumber root-associated communities at early stages of plant development and to be sensitive to increased microbial competition $(27,53)$.

The reduction in the Massilia population's size and root dominance in the suppressive soil was accompanied by significant changes in the relative abundance of additional bacteria (Table 6). Most notable was the increase in relative abundance of specific populations, namely the genera Rhizobium, Bacillus, Paenibacillus, and Streptomyces, members of which are frequently linked to plant health, biological control, and disease suppression $(9,31,34$, $47,49,51,56,63,73,75)$. Among these, the genus Streptomyces seems to be an important component in the disease-suppression process in the cucumber- $F$. oxysporum $\mathrm{f}$. sp. radicis-cucumerinum system $(26,63)$. The composition of the Streptomyces community, determined by PCR-DGGE examination, shifted significantly, resulting in a strong increase in the dominance of a specific population in suppressive soils after 3 days (Fig. 6) and on day 6 (Fig. 5). This shift was related mainly to an S. humidus-related population (99.9\% similarity according to sequence analysis of excised bands). Reports have indicated that some strains of $S$. humidus are antagonistic to different phytopathogenic fungi (40), and suppress Phytophthora capsici in vivo through direct antibiosis (phenylacetic acid and sodium phenylacetate) (28).

In naturally developed suppressive soils, abundance of the native antagonistic microorganisms may increase in the presence of a particular pathogen $(45,71,72)$. Therefore, the increase in populations of potential antagonists, such as Streptomyces spp., in suppressive soil is restricted to specific pathosystems. However, in the system studied here, in which suppressiveness was induced, the presence of $F$. oxysporum f. sp. radicis-cucumerinum triggered little change in the root bacterial community (Table 5). Acquisition of Pythium spp.-suppressive microbial consortia by cucumber seed in suppressive compost has been shown to be independent of the pathogen's presence $(48,54)$. It is possible that the change in root bacterial composition and the increased diversity could result in enhancement of competition for nutrients or in specific antagonism which may take place in the root zone following the pathogenic infection.

Manipulation of soil microbiota to create soil suppressiveness has more chances of success than the introduction of a biocontrol agent into a hostile and competitive environment. In this study, generating an appropriate soil environment with organic amendments resulted in a shift in root bacterial communities. Under the new microbial equilibrium, root infection by a virulent pathogen was contained by the root microbiome and disease severity was reduced.

\section{ACKNOWLEDGMENTS}

This work was partially supported by grants from the Chief Scientist of the Ministry of Agricultural and Rural Development. Contribution Number
712/12 series from the Agricultural Research Organization, The Volcani Center, Bet Dagan, Israel. We thank the staff of the laboratory and I. Lalzar for their technical assistance.

\section{LITERATURE CITED}

1. Abou-Shanab, R. A. I., van Berkum, P., and Angle, J. S. 2007. Heavy metal resistance and genotypic analysis of metal resistance genes in grampositive and gram-negative bacteria present in Ni-rich serpentine soil and in the rhizosphere of Alyssum murale. Chemosphere 68:360-367.

2. Alabouvette, C., Olivain, C., Migheli, Q., and Steinberg, C. 2009. Microbiological control of soil-borne phytopathogenic fungi with special emphasis on wilt-inducing Fusarium oxysporum. New Phytol. 184:529544 .

3. Altschul, S. F., Madden, T. L., Schaffer, A. A., Zhang, J., Zhang, Z., and Miller, W. 1997. Gapped BLASR and PSI-BLAST: A new generation of protein database search programs. Nucleic Acids Res. 25:3389-3402.

4. Bais, H. P., Weir, T. L., Perry, L. G., Gilroy, S., and Vivanco, J. M. 2006. The role of root exudates in rhizosphere interactions with plants and other organisms. Annu. Rev. Plant Biol. 57:233-266.

5. Bardi, L., Malusà, E., Rosso, F., Zoppellari, F., Aimo, S., Bertolone, E., Coppeta, A., and Berta, G. 2009. Rhizospheric microorganisms inoculum in soil to improve the yield and quality of agricultural products and the environmental impact of farming. Ann. Microbiol. 59:2.

6. Benítez, M. S., Tustas, F. B., Rotenberg, D., Kleinhenz, M. D., Cardina, J., Stinner, D., Miller, S. A., and Gardener, B. B. M. 2007. Multiple statistical approaches of community fingerprint data reveal bacterial populations associated with general disease suppression arising from the application of different organic field management strategies. Soil Biol. Biochem. 39:2289-2301

7. Bonanomi, G., Antignani, V., Capodilupo, M., and Scala, F. 2010. Identifying the characteristics of organic soil amendments that suppress soilborne plant diseases. Soil Biol. Biochem. 42:136-144.

8. Borneman, J., and Becker, O. 2007. Identifying microorganisms involved in specific pathogen suppression in soil. Annu. Rev. Phytopathol. 45:153172 .

9. Borrero, C., Trillas, M. I., Ordovás, J., Tello, J. C., and Avilés, M. 2004. Predictive factors for the suppression of Fusarium wilt of tomato in plant growth media. Phytopathology 94:1094-1101.

10. Buée, M., Reich, M., Murat, C., Morin, E., Nilsson, R. H., Uroz, S., and Martin, F. 2009. 454 Pyrosequencing analyses of forest soils reveal an unexpectedly high fungal diversity. New Phytol. 184:449-456.

11. Chao, A. 1984. Non-parametric estimation of the number of classes in a population. Scand. J. Stat. 11:265-270.

12. Chen, M.-H., and Nelson, E. B. 2008. Seed-colonizing microbes from municipal biosolids compost suppress Pythium ultimum damping-off on different plant species. Phytopathology 98:1012-1018.

13. Chen, W., Hoitink, H. A. J., Schmitthenner, F., and Tuovinen, O. H. 1988. The role of microbial activity in suppression of damping-off caused by Pythium ultimum. Phytopathology 78:314-322.

14. Compant, S., Mitter, B., Colli-Mull, J. G., Gangl, H., and Sessitsch, A. 2011. Endophytes of grapevine flowers, berries, and seeds: identification of cultivable bacteria, comparison with other plant parts, and visualization of niches of colonization. Microb. Ecol. 62:188-197.

15. Cook, R. J., and Baker, R. F. 1983. The Nature and Practice of Biological Control of Plant Pathogens. American Phytopathological Society, St. Paul, $\mathrm{MN}$.

16. Dohrmann, A. B., and Tebbe, C. C. 2005. Effect of elevated tropospheric ozone on the structure of bacterial communities inhabiting the rhizosphere of herbaceous plants. Appl. Environ. Microbiol. 71:77507758.

17. Dowd, S. E., Callaway, T. R., Wolcott, R. D., Sun, Y., McKeehan, T., Hagevoort, R. G., and Edrington, T. S. 2008. Evaluation of the bacterial diversity in the feces of cattle using $16 \mathrm{~S}$ rDNA bacterial tag-encoded FLX amplicon pyrosequencing. BMC Microbiol. 8:125.

18. Duijff, B. J., Recorbet, G., Bakker, P. A. H. M., Loper, J. A., and Lemanceau, P. 1999. Microbial antagonism at the root level is involved in the suppression of Fusarium wilt by the combination of nonpathogenic Fusarium oxysporum Fo47 and Pseudomonas putida WCS358. Phytopathology 89:1073-1079.

19. Gamliel, A., and Katan, J. 1991. Involvement of fluorescent pseudomonads and other microorganisms in increased growth response of plants in solarized soils. Phytopathology 81:494-502.

20. Gamliel, A., and Katan, J. 1993. Suppression of major and minor pathogens by fluorescent pseudomonads in solarized and nonsolarized soils. Phytopathology 83:68-75.

21. Garbeva, P., van Veen, J. A., and van Elsas, J. D.2004. Microbial diversity in soil: Selection of microbial populations by plant and soil type and implications for disease suppressiveness. Annu. Rev. Phytopathol. 42:243-270. 
22. Good, I. J. 1953. The population frequencies of species and the estimation of the population parameters. Biometrika 40:237-264.

23. Green, S. J., Michel, F. C., Hadar, Y., and Minz, D. 2007. Contrasting patterns of seed and root colonization by bacteria from the genus Chrysobacterium and from the family Oxalobacteraceae. ISME J. 1:291299.

24. Grönemeyer, J. L., Burbano, C. S., Hurek, T., and Reinhold-Hurek, B. 2011. Isolation and characterization of root-associated bacteria from agricultural crops in Kavango region of Namibia. Plant Soil. Online publication. doi:10.1007/s11104-011-0798-7

25. Hallmann, J., Rodríguez-Kábana, R., and Kloepper, J. W. 1999. Chitinmediated changes in bacterial communities of the soil, rhizosphere and within roots of cotton in relation to nematode control. Soil Biol. Biochem. 31:551-560.

26. Hammad, A. M. M., and El-Mohandes, M. A. O. 1999. Controlling Fusarium wilt disease of cucumber plants via antagonistic microorganisms in free and immobilized states. Microbiol. Res. 154:113117. Online publication. doi:10.1016/S0944-5013(99)80002-0

27. Hrynkiewicz, K., Baum, C., and Leinweber, P. 2010. Density, metabolic activity, and identity of cultivable rhizosphere bacteria on Salix viminalis in disturbed arable and landfill soils. J. Plant Nutr. Soil Sci. 173:747-756.

28. Hwang, B. K., Lim, S.W., Kim, B. S., Lee, J. Y., and Moon, S. S. 2001. Isolation and in vivo and in vitro antifungal activity of phenylacetic acid and sodium phenylacetate from Streptomyces humidus. Appl. Environ. Microbiol. 67:3739-3745.

29. Inbar, E., Green, S. J., Hadar, Y., and Minz, D. 2005. Competing factors of compost concentration and proximity to root affect the distribution of Streptomyces. Microb. Ecol. 50:73-81.

30. Kämpfer, P., Lodders, N., Martin, K., and Falsen, E. 2010. A revision of Massilia La Scola et al. 2000, with and emended description of the genus, and the inclusion of all species of the genus Naxibacter as new combinations and a proposal of Massilia consociata sp. nov.. Int. J. Syst. Evol. Microbiol. 61:1528-1533.

31. Katan, J., and Gamliel, A. Mechanisms of pathogen and disease control and plant-growth improvement involved in soil solarization. In: Soil Solarization: Theory and Practice. A. Gamliel and J. Katan, eds. American Phytopathological Society Press, St. Paul, MN. (In press.)

32. Kinkel, L. L., Bakker, M. G., and Schlatter, D. C. 2011. A coevolutionary framework for managing disease-suppressive soils. Annu. Rev. Phytopathol. 49:47-64.

33. Klein, E., Katan, J., and Gamliel, A. 2011. Soil suppressiveness to Fusarium disease following organic amendments and solarization. Plant Dis. 95:1116-1123.

34. Kloepper, J. W., Ryu, C. M., and Zhang, S. 2004. Induced systemic resistance and promotion of plant growth by Bacillus spp. Phytopathology 94:1259-1266.

35. Kyselková M., Kopecký J., Frapolli M., Défago G., Ságová-Marečková M., Grundmann G. L., and Moënne-Loccoz, Y. 2009. Comparison of rhizobacterial community composition in soil suppressive or conducive to tobacco black root rot disease. ISME J. Online publication. doi:10.1038/ismej.2009.61

36. Lane, D. J. 1991. 16S/23S rRNA sequencing. Pages 115-175 in: Nucleic Acid Techniques in Bacterial Systematic. E. Stackebrandt and M. Goodfelloe, eds. John Wiley and Sons, Chichester, UK.

37. La Scola, B., Birtles, R. J., Mallet, M. N., and Raoult, D. 1998. Massilia timonae gen. nov., sp. nov., isolated from blood of an immunocompromised patient with cerebellar lesions. J. Clin. Microbiol. 36:2847-2852.

38. Legendre, P., and Gallagher, E. D. 2001. Ecologically meaningful transformations for ordination of species data. Oecologia 129:271-280.

39. Lievens, B., Claes, L., Vakalounakis, D. J., Vanachter, A. C. R. C., and Thomma, B. P. H. J. 2007. A robust identification and detection assay to discriminate the cucumber pathogens Fusarium oxysporum f. sp. cucumerinum and f. sp. radicis-cucumerinum. Environ. Microbiol. 9:2145-2161.

40. Lim, S. W., Kim, J. D., Kim, B. S., and Hwang, B. K. 2000. Isolation and numerical identification of Streptomyces humidus strain S5-55 antagonistic to plant pathogenic fungi. Plant Pathol. J. 16:189-199.

41. Liu, B., Gumpertz, M. L., Hu, S., and Ristanio, J. B. 2007. Long-term effects of organic and synthetic soil fertility amendments on soil microbial communities and the development of southern blight. Soil Biol. Biochem. 39:2302-2316.

42. Ludwig, W., Strunk, O., Westram, R., Richter, L., Meier, H., and Yadhukumar, H., et al. 2004. ARB: a software environment for sequence data. Nucleic Acids Res. 32:1363-1371.

43. Manici, L. M., Caputo, F., and Baruzzi, G. 2005. Additional experiences to elucidate the microbial component of soil suppressiveness towards strawberry black root rot complex. Ann. Appl. Biol. 146:421-431.

44. Mazurier, S., Corberand, T., Lemanceau, P., and Raaijmakers, J. M. 2009. Phenazine antibiotics produced by fluorescent pseudomonads contribute to natural soil suppressiveness to Fusarium wilt. ISME J. 3:977-991.
45. Mazzola, M. 2002. Mechanisms of natural soil suppressiveness to soilborne diseases. Antonie Leeuwenhoek 81:557-564.

46. Mazzola, M. 2004. Assessment and management of soil microbial community structure for disease suppression. Annu. Rev. Phytopathol. 42:35-59.

47. Mazzola, M. 2007. Manipulation of rhizosphere bacterial communities to induce suppressive soils. J. Nematol. 39:213-220.

48. McKellar, M. E., and Nelson, E. B. 2003. Compost-induced suppression of Pythium damping-off is mediated by fatty-acid-metabolizing seedcolonizing microbial communities. Appl. Environ. Microbiol. 69:452-460.

49. Mendes, R., Kruijt, M., de Bruijn, I., Dekkers, E., van der Voort, M., Schneider, J. H. M., Piceno, Y. M., DeSantis, T. Z., Andersen, G. L., Bakker, P. A. H. M., and Raaijmakers, J. M. 2011. Deciphering the rhizosphere microbiome for disease-suppressive bacteria. Science 332:1097-1100.

50. Muyzer, G., de Waal, E. C., and Uitterlinden, A. G. 1993. Profiling of complex microbial populations by denaturing gradient gel electrophoresis analysis of polymerase chain reaction-amplified genes coding for $16 \mathrm{~S}$ rRNA. Appl. Environ. Microbiol. 59:695-700.

51. Nautiyal, C. S. 1997. Rhizosphere competence of Pseudomonas sp. NBRI9926 and Rhizobium sp. NBRI9513 involved in the suppression of chickpea (Cicerarietinum L.) pathogenic fungi. Microbiol. Ecol. 23:145158.

52. Nelson, E. B. 2004. Microbial dynamics and interactions in the spermosphere. Annu. Rev. Phytopathol. 42:271-309.

53. Ofek, M., Hadar, Y., and Minz, D. 2009. Comparison of effects of compost amendment and of single-strain inoculation on root bacterial communities of young cucumber seedlings. Applied Environ. Microbiol. 75:6441-6450.

54. Ofek, M., Hadar, Y., and Minz, D. 2011. Colonization of cucumber seeds by bacteria during germination. Environ. Microbiol. Online publication. doi:10.1111/j.1462-2920.2011.02551.x

55. Pharand, B., Carisse, O., and Benhamou, N. 2002. Cytological aspects of compost-mediated induced resistance against Fusarium crown and root rot in tomato. Phytopathology 92:424-438.

56. Postma, J., Scheper, R. W. A., and Schilder, M. T. 2010. Effect of successive cauliflower plantings and Rhizoctonia solani AG 2-1 inoculations on disease suppressiveness of suppressive and conducive soil. Soil Biol. Biochem. 42:804-812.

57. Postma, J., Willemsen-de Klein, M. J. E. I. M., and van Elsas, J. D. 2000. Effect of the indigenous microflora on the development of root and crown rot caused by Pythium aphanidermatum in cucumber grown on rockwool. Phytopathology 90:125-133.

58. Raaijmakers, J. M., Paulitz, T. C., Steinberg, C., Alabouvette, C., and Moënne-Loccoz, Y. 2009. The rhizosphere: a playground and battlefield for soilborne pathogens and beneficial microorganisms. Plant Soil 321:341-361.

59. Ruppel, S., Rühlmann, J., and Merbach, W. 2006. Quantification and localization of bacteria in plant tissues using quantitative real-time PCR and online emission fingerprinting. Plant Soil 268:21-35.

60. Schloss, P. D., Westcott, S. L., Ryabin, T., Hall, J. R., Hartmann, M., Hollister, E. B., Lesniewski, R. A., Oakley, B. B., Parks, D. H., Robinson, C. J., Sahl, J. W., Sters, B., Thallinger, G. G., Van Horn, D. J., and Weber, C. W. 2009. Introducing MOTHUR: Open-source, platform-independent, community-supported software for describing and comparing microbial communities. Appl. Environ. Microbiol. 75:7537-7541.

61. Shetty, K. G., Subbarao, K. V., Huisman, O. C., and Hubbard, J. C. 2000. Mechanism of broccoli-mediated Verticillium wilt reduction in cauliflower. Phytopathology 90:305-310.

62. Shiomi, Y., Nishiyama, M., Onizuka, T., and Marumoto, T. 1999. Comparison of bacterial community structures in the rhizoplane of tomato plants grown in soils suppressive and conducive towards bacterial wilt. Appl. Environ. Microbiol. 65:3996-4001.

63. Singh, P. P., Shin, Y. C., Park, C. S., and Chung, Y. R. 1999. Biological control of Fusarium wilt of cucumber by chitinolytic bacteria. Phytopathology 89:92-99.

64. Steinberg, C., Edel-Hermann, V., Alabouvette, C., and Lemanceau, P. 2006. Soil suppressiveness to plant diseases. Pages 455-477 in: Modern Soil Microbiology, 2nd ed. J. D. Van Elsas, J. K. Jansson, and J. T. Trevors, eds. CRC Press, Boca Raton, FL.

65. Tuitert, G., Szczech, M., and Bollen, G. J. 1998. Suppression of Rhizoctonia solani in potting mixtures amended with compost made from organic household waste. Phytopathology 88:764-773.

66. Vallad, G. E., Cooperband, L., and Goodman, R. M. 2003. Plant foliar disease suppression mediated by composted forms of paper mill residuals exhibits molecular features of induced resistance. Physiol. Mol. Plant Pathol. 63:65-77.

67. van Elsas J. D., Costa, R., Jansson, J., Sjöling, S., Bailey M., Nalin, R., Vogel, T. M., and van Overbeek, L. 2008. The metagenomics of disease suppressive soils-experiences from the METACONTROL project. 
Trends Biotechnol. 26:591-601.

68. van Elsas, J. D., Garbeva, P., and Salles, J. 2002. Effects of agronomical measures on the microbial diversity of soils as related to the suppression of soil-borne plant pathogens. Biodegradation 13:29-40.

69. van Elsas, J. D., Kielak, A. M., and Cretoiu, M. S. 2011. The Metagenomics of pathogen-suppressive soils. Pages 277-286 in: Handbook of Molecular Microbial Ecology I: Metagenomics and Complementary Approaches. F. J. de Bruijn, ed. Wiley-Blackwell, Hoboken, NJ.

70. Vieweg, M. F., Hohnjec, N., and Küster, H. 2005. Two genes encoding different truncated hemoglobis are regulated during root nodule and arbuscular mycorrhiza symbioses of Medicago trunctula. Planta 220:757766.

71. Weller, D. M., Raaijmakers, J. M., Gardener, B. B. M., and Thomashow, L. S. 2002. Microbial populations responsible for specific soil suppressiveness to plant pathogens. Annu. Rev. Phytopathol. 40:309-348.

72. Westphal, A., and Becker, J. O. 2001. Components of soil suppressiveness against Heterodera schachatii. Soil Biol. Biochem. 33:9-16.

73. Workneh, F., and van Bruggen, A. H. C. 1994. Microbial density, composition, and diversity in organically and conventionally managed rhizosphere soil in relation to suppression of corky root of tomatoes. Appl. Soil Ecol. 1:219-230.

74. Yang, C. H., Crowley, D. E., and Menge, J. A. 2001. 16S rDNA fingerprinting of rhizosphere bacterial communities associated with healthy and Phytophthora infected avocado roots. FEMS Microbiol. Ecol. 35:129-36.

75. Yin, B., Valinsky, L., Gao, X., Becker, J. O., and Borneman, J. 2003. Bacterial rRNA genes associated with soil suppressiveness against the plant-parasitic nematode Heterodera schachtii. Applied Environ. Microbiol. 69:1573-1580.

76. Yogev, A., Raviv, M., Hadar, Y., Cohen, R., Wolf, S., Gil, L., and Katan, J. 2010. Induced resistance as a putative component of compost suppressiveness. Biol. Control 54:46-51. 